\title{
INVESTIGATION OF THE ROLE OF CERTAIN FACTORS AFFECTING THE CONTRAST IN LASER MARKING
}

\author{
L. Lazov ${ }^{1, *}$, A. Atanasov ${ }^{2}$, N. Angelov ${ }^{3}$ \\ ${ }^{1}$ Technical University of Gabrovo, Hadzhi Dimitar 4, 5300 Gabrovo, Bulgaria, \\ ${ }^{2}$ BAN, Pulsvet, Charigradsko Shose 72, Sofia \\ ${ }^{3}$ Technical University of Gabrovo, Hadzhi Dimitar 4, 5300 Gabrovo, Bulgaria
}

\begin{abstract}
An investigation has been made of dependence of marking contrast on surface roughness, spacing between hatches (that is the pitch between hatches) and the speed for products made of tool steel. Experiments made concern pulse laser $\mathrm{CuBr}$ utilizing MOPA system.
\end{abstract}

Keywords: laser marking, contrast, roughness.

\section{INTRODUCTION}

Laser marking is a method for labeling various kinds of objects using a laser $[1,2]$. Marking of products becomes of ever greater importance given the context of global manufacture and trade. It allows quality and manufacturing process control along its entire line from input to output. On the market level marking allows making claims against manufacturers thus getting to the concrete faulty element whenever flaws and defects are found in the products.

Markings facilitate and simplify the activities of all participants in the processing sequence such as manufacturers, suppliers, carriers, customs offices, retailers, international and local control bodies, consumers.

Quality of marking is of great importance while handling products in warehouses, sales outlets etc. This underlies the effective work of bar and matrix code readers. A principal requirement for long lasting of marking and its subsequent retention during the period of operation is obtaining of high contrast. Therefore, it is necessary to investigate certain factors affecting marking contrast.

The paper studies an impact of surface roughness $R_{a}$, pitch $\Delta x$ and speed of marking $v$ upon contrast $k^{*}$ and henceforth upon the quality of laser marking for samples made of tool steel.

\section{PRESENTATION}

Laser marking can be divided into raster and vector type depending on the image generation [3].
Due to the introduction of matrix and bar codes as obligatory, the recent years saw the predominant use of the raster type of marking. This is why the experiments carried out within this investigation have been directed toward clearer understanding of the impact of certain factors upon marking contrast when that particular method is utilized.

Vector type marking is effected through inscribing symbols or by means of contour generation (Fig. 1a).

With raster marking the image is generated by means of marking of sequential lines at a preset pitch $\Delta x$ - fig. 1b. This method is employed for larger dimensions of the surface being marked (such as company logo, matrix codes etc).

In real practice a combination of both methods is often used. In this way it is possible to mark any kind of inscription: character-digital, graphic, symbols, bar codes and 2D codes, etc. It should be noted that $2 \mathrm{D}$ codes are a serious barrier for rogue companies and to a large extent contribute to the overall success in combating counterfeit products.

A basic factor in marking contrast is a ratio between the perceived marked surface and its background. It depends on the intensity of the brightest and darkest sections. Contrast is expressed by

$$
k^{*}=\frac{I_{\text {max }}-I_{\text {min }}}{I_{\text {max }}+I_{\text {min }}},
$$

whereby $I_{\max }$ is the intensity of the background around the image, $I_{\min }$ - is the intensity of the darkest marked section of the surface.

\footnotetext{
"Corresponding author: lazov@tugab.bg
} 


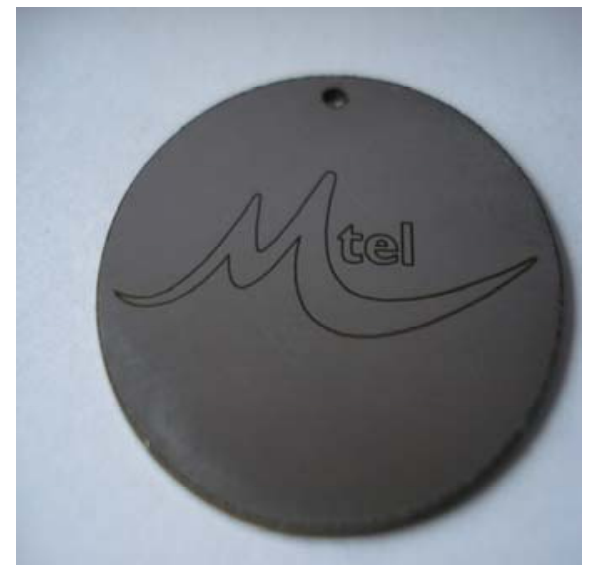

(a)

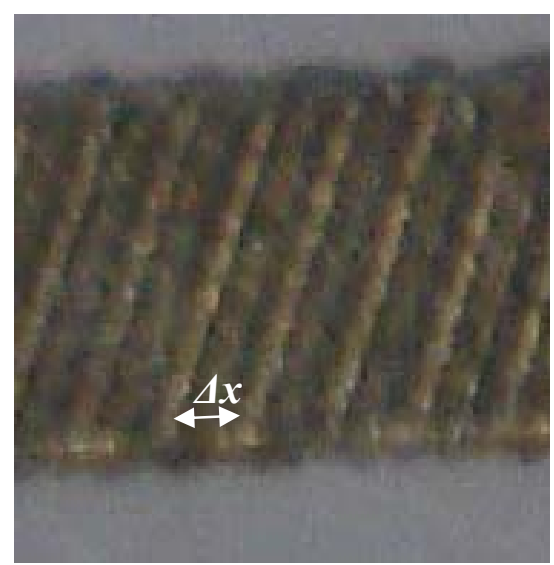

(b)

Figure 1. (a) Vector type of marking and (b) section of raster marking on steel sample

Contrast $k^{*}$ can be determined in relative units as percentage by the grey scale; it is assumed that the background of the sample surface marked has contrast $k^{*}=0 \%$, and the contrast of the darkest possible marking is $k^{*}=100 \%$. According to the grey scale of BMP each image can be rendered as a number between 0 (black) and 255 (white) [4]. Then the two reference numbers $N_{f}$ (for the background) and $N_{b}$ (the darkest possible marking) are used. A black and white photo is taken of a section of the marked zone for the purpose of contrast measuring. Using the grey scale a comparison is made between the photographed section and the references thus reading the respective value of $N_{x}$ by the scale. Contrast $k_{x} *$ is determined by way of linear interpolation from the expression

$$
k_{x}^{*}=\frac{N_{f}-N_{x}}{N_{f}-N_{b}} \cdot 100 \% \text {. }
$$

\section{EXPERIMENTAL PART}

\section{Materials used}

Samples of carbon tool steels Y 11, Y12 and rapid steels P6M5K5 and P6M5 have been used in these investigations.

Work surfaces of samples have been scrubbed beforehand with emery (sand) paper №№ 120 , $180,280,420$ and 600 with roughness within the interval $R_{a} \in[0,63 ; 1,19] \mu \mathrm{m}$.

All marked and investigated zones are based on the raster method.

\section{Laser source}

Pulslight manufacturing laser of $\mathrm{CuBr}[5]$ is used for the purpose of laser marking of products made of tool steel (Fig. 2). The basic parameters of the laser source are:

$$
\begin{array}{ll}
\text { Wave length } & \lambda=511 \mathrm{~nm} \& 578 \mathrm{~nm} ; \\
\text { Rated power } & \mathrm{P}_{\mathrm{H}}=10,0 \mathrm{~W} ; \\
\text { Duration of pulses } & \tau=30 \mathrm{~ns} ; \tau=50 \mathrm{~ns} \\
\text { Frequency } & \nu=19,0 \mathrm{kHz} \\
\text { Pulse energy } & E=0,51 \mathrm{~mJ} \\
\text { Quality of beam } & M^{2}<1,5
\end{array}
$$

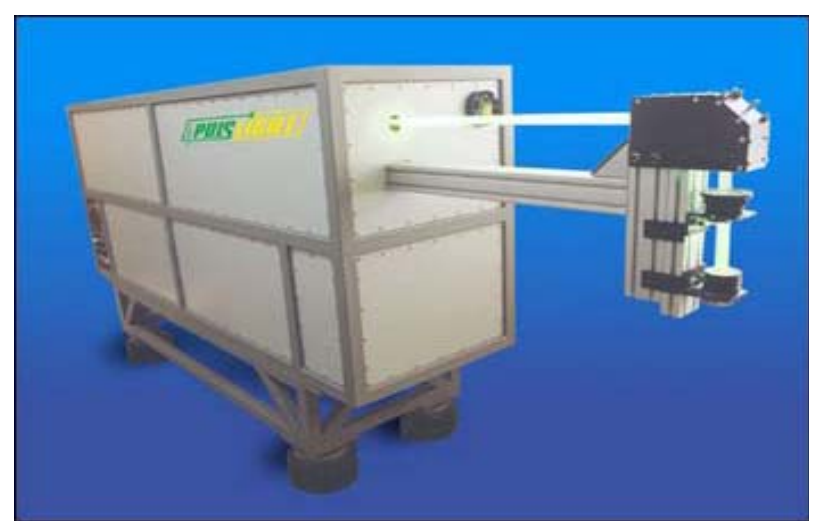

Figure 2. Laser system for marking CBL MOPA with laser of $\mathrm{CuBr}$, developed by scientists and researchers from Bulgarian Academy of Sciences

\section{METHODOLOGY}

All experiments have been conducted with triple hatching of one and the same section of the work zone; the marked surface is covered with hatches of definite spacing (pitch) and positioned at various angles (for example, $0^{\circ}, 60^{\circ}$ and $120^{\circ}$ or $45^{\circ}$, $90^{\circ}$ and $135^{\circ}$ ). Triple hatching is used because it ensures better contrast of marking as compared to single and double hatching. In real practice single hatching is the most commonly used method which saves time. 
Experimental investigations have been carried out in three major directions:

- Investigation of the impact of surface roughness $R_{a}$ of tool steel samples upon the contrast $k^{*}$ of marking;

- Investigation of the spacing (pitch) $\Delta x$ impact upon the contrast $k^{*}$ of marking

- Investigation of the speed impact $\mathrm{v}$ upon the contrast $k^{*}$ of marking

Investigation of the impact of surface roughness $R_{a}$ of tool steel samples upon the contrast $k^{*}$ of marking

Roughness may arise from various reasons mostly connected with the type of surface treatment, surface geometry, the state of the processing tool, operational mode, type and structure of the processed material, etc. The total number of rough points which shape the surface relief and are evaluated for a certain section which does not contain distortions in shape and waviness, is referred to as surface roughness. Surface roughness of machine parts impacts their operational performance as well. A series of experiments have investigated the impact of surface roughness $R_{a}$ upon the contrast $k^{*}$ of laser marking.

Samples of rapid steel type P6M5K5 have been used, with different roughness, that decreases from sample 1 to sample 5 (see fig. 3). The marking mode includes:

Power density of laser radiation $q_{S}=8,49.10^{9} \mathrm{~W} / \mathrm{m}^{2}$; Speed of marking

Duration of pulses

Diameter of work spot

Spacing (pitch)

$v=50 \mathrm{~mm} / \mathrm{s}$

$\tau=50 \mathrm{~ns}$

$d=30 \mu \mathrm{m}$;

$\Delta x=100 \mu \mathrm{m}$.

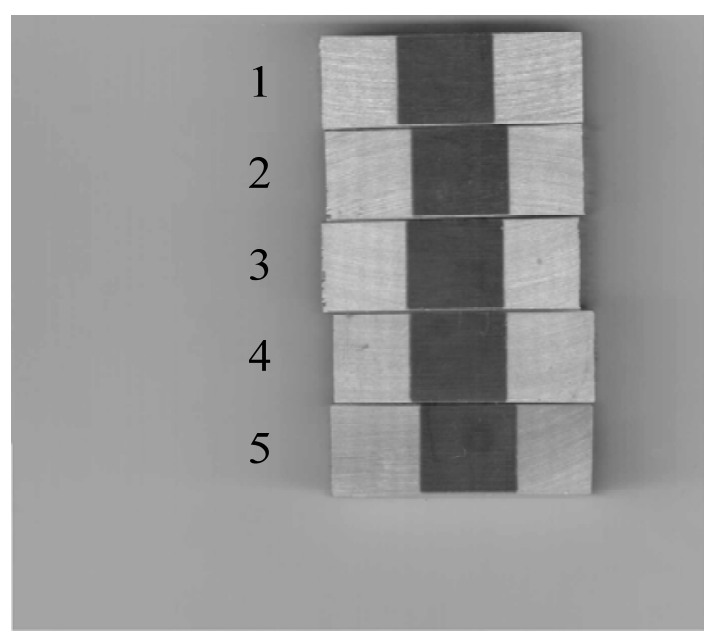

Figure 3. Raster marked samples of rapid steel P6M5K5 with various roughness $R_{a}$ of the surface within the range $R_{a} \in[0,63 ; 1,19] \mu \mathrm{m}$
Fig. 4 presents the resultant dependency of the contrast $k^{*}$ on roughness $R a$. It is evident from the analysis that the surface roughness $R_{a}$ of the sample slightly affects the contrast $k^{*}$ of the marking. The variation of contrast $\mathrm{k}^{*}$ for the interval of roughness under investigation is below $2 \%$ which in turn does not impact the quality of marking especially when using reading scanners to obtain data from 2D codes. This conclusion is also confirmed by the visual perception of the samples' contrast in Fig. 4.

Roughness of samples for the interval under investigation does not substantially affect the contrast of marking. This is one of the fundamental conclusions following the investigations. Ensuing analysis of results indicates that laser marking employing raster method does not necessitate additional grinding of the product or the deposition of any coating in order to obtain marking of better contrast. In this way lower cost and greater effectiveness are achieved.

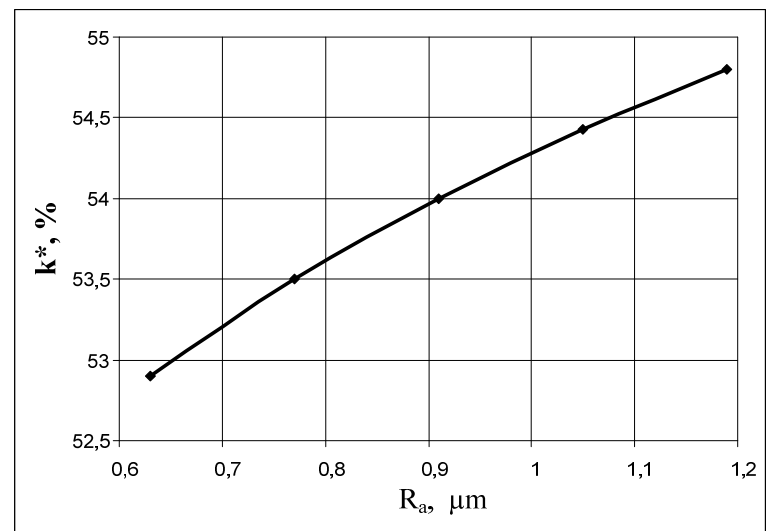

Figure 4. Graph of contrast $k^{*}$ dependency on roughness $R_{a}$ for raster marked samples of rapid tool steel P6M5K5

Investigation of spacing (pitch) impact on the contrast $k^{*}$ of marking

During investigations the spots with dimensions $3 \mathrm{~mm} \times 3 \mathrm{~mm}$ were marked on samples made of steel $\mathrm{Y} 11$ and $\mathrm{Y} 12$. These marked spots had different spacing which varies for three columns within the interval $\Delta x \in[40,160] \mu \mathrm{m}$ by $20 \mu \mathrm{m}$; the topmost spot being marked by spacing(pitch) of $\Delta x=$ $40 \mu \mathrm{m}$. Fig. 5 presents a photograph of the marked spots of carbon tool steel $Y 12$. In the first column the last layer of hatches are marked at an angle of $45^{\circ}$, in the second at an angle of $90^{\circ}$ and in the third at an angle of $135^{\circ}$. follows:

The operating mode of the laser source is as

Power density of laser radiation $q_{S}=7,08.10^{9}$ $\mathrm{W} / \mathrm{m}^{2}$;

Speed of marking $\quad v=200 \mathrm{~mm} / \mathrm{s}$; 
Duration of pulses

$\tau=50 \mathrm{~ns}$

Diameter of work spot

$d=30 \mu \mathrm{m}$;

Triple hatching at angles of $45^{\circ}, 90^{\circ}$ and $135^{\circ}$

Investigation analysis indicated that the sequence of hatching in the last layer does not affect the contrast of marking.

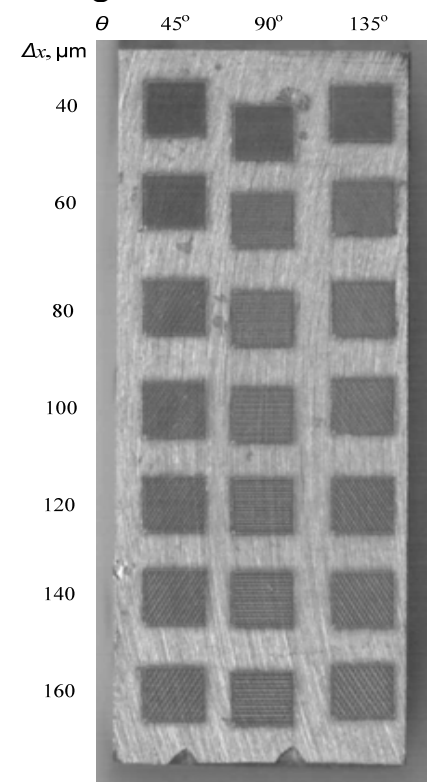

Figure 5. Raster marked sample of carbon tool steel type Y12 with various spacing (pitch) $\Delta x$, power density $q_{S}=7,08.10^{9} \mathrm{~W} / \mathrm{m}^{2}$ and speed $v=200 \mathrm{~mm} / \mathrm{s}$

Fig. 6 presents a graph of the dependency of the contrast of marking $k^{*}$ on the spacing (pitch) $\Delta x$ for sample of carbon tool steel type y12. What is observed is a non-linear decrease of the value of the marked zone with the increment of the spacing (pitch). The curve is steeper with a spacing (pitch) of $\Delta x>80 \mu \mathrm{m}$ which corresponds to the rapid decrease of the marking contrast within this interval. It should be borne in mind that the diameter of the work spot is constant: $d=30 \mu \mathrm{m}$ and within the interval $\Delta x \in[80,160] \mu \mathrm{m}$ the coefficient of filling the marked zone is within the range $k_{f} \in[74,1$; $50,6] \%$. This fact explains the rapid decrease of the marking's contrast in the interval under investigation.

Investigation of the impact of speed $\mathrm{v}$ upon the marking contrast $k^{*}$

The speed of marking is a very important manufacturing parameter for the process of laser marking of products; the higher the speed of marking, the lesser the time interval needed for marking of a product. In this way better cost effectiveness and time economy are achieved. These considerations are supported only in case of markings of clear cut con- trast with good quality laser markings to be achieved.

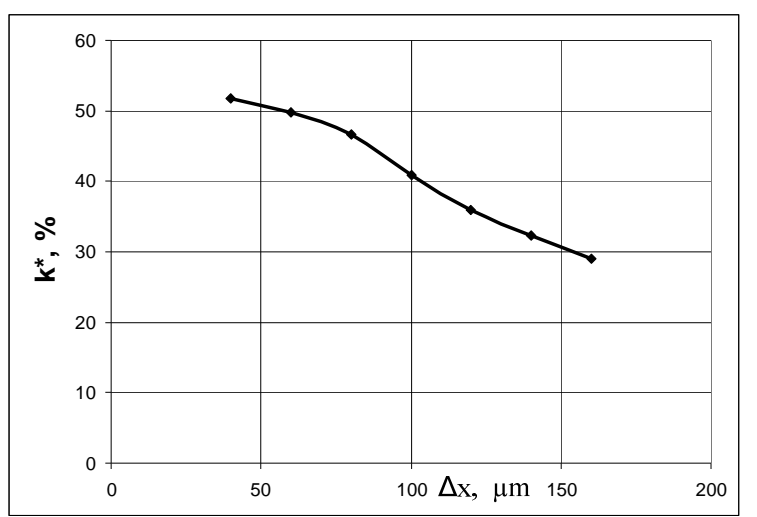

Figure 6. Graph that presents dependency of the marking contrast $k^{*}$ on the spacing (pitch) $\Delta x$ for sample of carbon tool steel type $\mathrm{Y12}$. Laser of $\mathrm{CuBr}$ having power density $q_{S}=7,08.10^{9} \mathrm{~W} / \mathrm{m}^{2}$ and speed $v=200 \mathrm{~mm} / \mathrm{s}$

A series of experiments have been conducted with samples of rapid tool steel type P6M5 and $\mathrm{Cu}-$ $\mathrm{Br}$ laser, aiming at achievement of optimum ratio between rapid marking and resultant marking contrast.

Marking has been made with the following optimum parameters:

Power density of laser radiation $q_{S}=7,08.10^{9} \mathrm{~W} / \mathrm{m}^{2}$; Diameter of work spot $\quad d=30 \mu \mathrm{m}$;

Duration of pulses $\tau=30 \mathrm{~ns}$ Spacing (pitch) $\Delta x=70 \mu \mathrm{m}$. Triple hatching at angles of $45^{\circ}, 90^{\circ}$ and $135^{\circ}$.

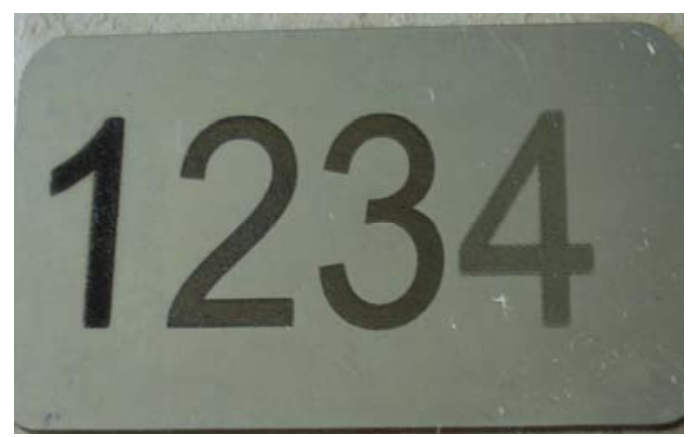

Figure 7. Laser marking of carbon tool steel type $\mathrm{Y} 12$ made with laser $\mathrm{CuBr}$ featuring power density of $q_{S}=$ $7,08.10^{9} \mathrm{~W} / \mathrm{m}^{2}$ and spacing (pitch) $\Delta x=70 \mu \mathrm{m}$ : digit 1 - at speed of $v=25 \mathrm{~mm} / \mathrm{s}$; digits 2 and 3 - at speed of $v$ $=100 \mathrm{~mm} / \mathrm{s} ;$ digit 4 - at speed of $v=500 \mathrm{~mm} / \mathrm{s}$

Fig. 8 presents a graph of the dependency of marking contrast $k^{*}$ upon the speed $v$ for sample of carbon tool steel type $\mathrm{Y} 12$ made with laser CuBr. A non-linear decline in the marking contrast is observed along with an increase in speed $v$. At marking speed of $v=25 \mathrm{~mm} / \mathrm{s}$ the contrast $k^{*}=62,3 \%$ whereas at marking speed of $v=150 \mathrm{~mm} / \mathrm{s}$ the contrast is $k^{*}=39,9 \%$, i.e. a five time increase in speed re- 
duces marking contrast with $22,4 \%$. The contrast is twice greater than the lower limit at which it is still possible to read the information contained in the DATA MATRIX code and according to [6] $k^{*}=$ $20,0 \%$. With these parameters of marking, the range of marking speeds is $v \in[25,150] \mathrm{mm} / \mathrm{s}$ for which the decrease in contrast sharpness does not break the permissible limit needed for computerized data processing (by means of reading scanners).

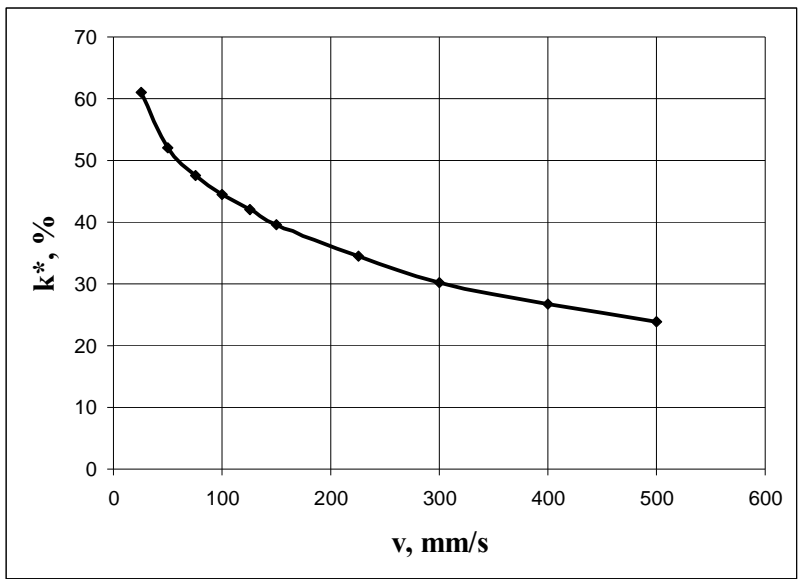

Figure 8. Graph that presents dependency of marking contrast $k^{*}$ upon the speed $v$ for sample of carbon tool steel type $\mathrm{Y} 12$ made with laser $\mathrm{CuBr}$, featuring power density $q_{S}=7,08.10^{9} \mathrm{~W} / \mathrm{m}^{2}$ and spacing (pitch) $\Delta x=70$ $\mu m$

\section{CONCLUSION}

Investigation of the key factors which affect the contrast of laser marking is of great importance in achieving higher quality of marked products and the selection of optimum manufacturing modes for each particular case.

This investigation makes observation of a limited number of factors affecting quality in laser marking of products made of tool steel. The role of other factors which impact the process of laser marking such as power density of laser radiation, absorption capacity of material (that is the coefficient of reflection), coefficient of overlapping, number of repetitions in inscribing lines etc, will be the subject of another investigation on our part.

\section{REFERENCES}

[1] J. T. Luxon, Industrial Lasers and their Applications, Prentice Hall, Inc., Englewood Cliffs, New Jersey 1985.

[2]. J. C. Ion, Laser Processing of Engineering Materials: Principles, Procedure and Industrial Application, Chapter 15: Marking, Elsevier Butterworth-Heinemann, Oxford 2005.

[3] J. Henkelmann, Laser Beschriften, LTJ, 2 (2008).

[4] http://lab.fs.unilj.si/kolt/LastedNet/lpkf/intro.pdf

[5] H. Bergmann, R. Salimbeni, N. Sabotinov, J. Mizeraczyk, C. Wallimann, I. Kostadinov, Development of a System Based on a High Power and High Efficiency Copper Bromide Laser for Precision Materials Processing, Project NATO SfP - 972685 „NATO SfP - Copper Bromide Laser”, Final Report, November 2002.

[6] Faißt Birgit Beschriften mit diodengepumptem Festkörperlaser, TRUMPF Laser $\mathrm{GmbH}$, (2006) 3-33.

\section{ИСТРАЖИВАҢЕ УЛОГЕ ОДРЕЪЕНИХ ФАКТОРА КОЈИ УТИЧУ НА КОНТРАСТ ПРИ ЛАСЕРСКОМ МАРКИРАФУ}

Сажетак: У овом раду приказани су резултати испитивања о томе како контраст ласерског маркирања (означавања) зависи од глаткоће површине, размака између линија сјенчења (односно корака између њих) и брзине маркирања на предметима начињеним од алатних челика. Експерименти су извршени употребом импулсног $\mathrm{CuBr}$ ласера и коришћењем МОПА система.

Кључне ријечи: ласерско маркирање, контраст, глаткоћа. 